\title{
A Study on Construction of Division System in China's Travel Agency Industry
}

\author{
Yufeng Yong \\ School of Management, Jinan University, Guangzhou, China \\ Email:monica_yong@163.com
}

How to cite this paper: Yong, Y.F. (2017) A Study on Construction of Division System in China's Travel Agency Industry. Journal of Service Science and Management, 10, 437-446. https://doi.org/10.4236/jssm.2017.105035

Received: September 25, 2017

Accepted: October 28, 2017

Published: October 31, 2017

Copyright (C) 2017 by author and Scientific Research Publishing Inc. This work is licensed under the Creative Commons Attribution International License (CC BY 4.0).

http://creativecommons.org/licenses/by/4.0/

(c) (i) Open Access

\begin{abstract}
The first travel agency in China, established in Shanghai Commercial Bank in 1923, had been oriented to administrative business up to early stage of the reform and opening up and gradually shifted from a policy-oriented stage to a market-oriented stage from 1978 to the present. It is fundamentally different from overseas travel agency which spontaneously occurs in market. As market economy is becoming perfect, improvement for division system in China's travel agency industry is extremely urgent. In this paper, division system in China's travel agency industry is studied to analyze its present state. After being applied reasonably in the period of planned economy, horizontal division system in China's travel agency industry gradually became unreasonable due to failure to cater to growth of market flexibly in a system of shift to market economy: Economies of scale cannot be formed; conventional travel products face multiple crises; and barrier to costs and risk of being imitated exist in occurrence of new travel products. Vertical division system has numerous advantages but multiple barriers in its construction. In this regard, major countermeasures are proposed for construction of vertical division system in China's travel agency industry.
\end{abstract}

\section{Keywords}

Travel Agency Industry, Division System, Barriers, Countermeasures

\section{Introduction}

Division system in travel agency industry refers to roles played by different types of travel agencies in market regions and product circulation links and mutual relation between those agencies. It may occur spontaneously under drive by endogenetic power from market economy system or through division under guidance of governmental administrative departments. Presently, there are three 
major division systems in the world, vertical, horizontal, and mixed. Vertical division system, also called natural division system, occurs in the process for providing travelers with services and in a vertical state, relevant travel supplier-travel agency-traveler. In Profession Travel Agency Management written by Chuck Y. Gee in 1990, he underlined difference between concepts of travel operator and wholesaler and believed "wholesalers may not be engaged in retail and they generally form new quotation by purchasing and combining existing services while operators generally produce new products like sightseeing tour and provide their own services. Wholesalers are not inclined to ground services as operators are." Horizontal division system is divided under intervention of administrative power and in different market regions or business scopes where travel agencies are located [1]. Under administrative power from government, travel agencies are divided into several classes and types. Meanwhile, travel service market is divided into several submarkets, such as inbound travel, domestic travel and abroad travel. Travel agencies operate corresponding submarkets accordingly. So-called mixed division system refers to a transitional division state, peculiar to travel agency industry, from horizontal division system under guidance of government to natural vertical division system in institutional change or economic system shift [2]. Difference among these three systems lies in their mode of production. Economic system plays a decisive role in division system. In countries with planned economic system, due to government intervention, horizontal division system is developed generally. In countries with full market economic system, vertical division system is formed. Mixed division is just a form of transition. Another significant difference lies in change of investor. Vertical division system grows in full market environment and its investors are enterprises engaged in market competition. However, in horizontal division system, competent departments are led by government serves as investors. In mixed horizontal division system, both government and enterprise can be engaged as investors on an important premise that all investors are in a fair competitive environment without any exception [3].

\section{Literature Review: Present State of Division System in Travel Agency Industry}

In Europe and America, generally, domestic travel is developed first; then outbound travel occurs before or at the same time with inbound travel [4].Such development process of travel conforms to the general pattern of development, namely natural transition from junior to senior. Vertical division system (natural division system) is apt to occur. Table 1 shows difference between division systems in travel agency industry:

Division in China's travel agency industry was determined under government intervention and in a form of law. The division system is typically horizontal. In China, outbound travel was developed, following inbound travel and domestic travel. When inbound travel grew, business of travel agency was based on go- 
vernmental reception. Thus, intervention from administrative power was inevitable. Domestic agency, international agency, class I agency, class II agency and class III agency occurred through man-made division of market regions. Thus, the possibility that vertical division system occurs in China's travel agency industry was strangled.

China's travel agency industry had been operated under governmental guidance and in a form of horizontal division for a long time. This is a result under combined action of industrial policies and regulations, traditional economy system, and current market mechanism. Division system for China's travel agencies is roughly divided to three stages, as shown in Table 2.

While establishment of horizontal division system in China played an important role in a historical period, in fact, such unnatural and man-made division has given rise to inefficient and disorderly operation of China's travel agency industry. Due to its drawbacks, horizontal division system have brought a series of problems to China's travel agency industry, such as disorder in market and low performance, as well as violations like "no economics of sale in large-sized agency" and "subordination", similar travel products, and vicious price competition. On the contrary, travel agencies in Europe and America with typical vertical division system are operated smoothly.

It is an issue of interest from the industry in recent years to settle those

Table 1. Comparison for difference between division systems in travel agency industry [5].

\begin{tabular}{|c|c|c|c|}
\hline Item & Vertical division system & Horizontal division system & Mixed division system \\
\hline Typical example & Europe and America & China and Korea & Japan \\
\hline Classification method & $\begin{array}{l}\text { Two classes: wholesale operator and agent } \\
\text { Three classes: operator, wholesaler, retailer }\end{array}$ & $\begin{array}{l}\text { Two classes: domestic and } \\
\text { international } \\
\text { Three classes: classes I, II, III }\end{array}$ & $\begin{array}{l}\text { Common travel agency, } \\
\text { domestic travel agency, } \\
\text { and travel agency store }\end{array}$ \\
\hline Basis for classification & Role played in service & Operation scope & Both \\
\hline Sale channel & Sale in the charge of retailer & Direct sale & Both \\
\hline Business scope & $\begin{array}{l}\text { Production in the charge of wholesale } \\
\text { operator and sale in the charge of retailer }\end{array}$ & $\begin{array}{l}\text { Taking full charge of overall } \\
\text { process }\end{array}$ & Both \\
\hline Characteristics of framework & $\begin{array}{l}\text { "large and complete", } \\
\text { "small and simple" }\end{array}$ & "small and complete" & $\begin{array}{l}\text { "large and complete", } \\
\text { "small and complete" }\end{array}$ \\
\hline Investor & Enterprise & $\begin{array}{l}\text { Government and its competent } \\
\text { department }\end{array}$ & Diversified \\
\hline
\end{tabular}

Table 2. Comparison among three stages of division system for China's travel agencies.

\begin{tabular}{|c|c|c|c|}
\hline Item & $\begin{array}{c}\text { Stage I } \\
(1949-1984)\end{array}$ & $\begin{array}{c}\text { Stage II } \\
(1985-1996)\end{array}$ & $\begin{array}{c}\text { Stage III } \\
\text { (1996-the present) }\end{array}$ \\
\hline Form of division & (outreach + reception) agencies & (class I + II + III) agencies & (international + domestic) agencies \\
\hline Division basis & Administrative order & Travel Agencies Management Rules & Travel Agencies Management Rules \\
\hline Business division & Outreach + reception & International + intermediate + domestic & International + domestic \\
\hline
\end{tabular}


problems through establishment of vertical division system. As Wei Xiao'an wrote in Report on Growth of Travel Agency Industry in China-Analysis for Situation of Market Competition and Operation Countermeasures, vertical division system is a trend of change in and an ideal state of division system for travel agencies in China. Wang Lei believes, at present, foundation for reform of division system for travel agencies in China has been basically formed, and an historic opportunity of shift from conventional horizontal division system to vertical division system lies ahead [6]. Huang Li thinks basic characteristics of current agency industry in China are large-sized agencies are of a small number but a large scale and occupy a large market share, and medium and small-sized travel agencies are of a large number and a high proportion and are distributed geographically and reasonably, which has provided a favorable foundation for travel agencies operation system to be oriented to the goal that large-sized travel agencies are grouped, medium-sized travel agencies are specialized and small travel agencies are operated online [7]. Cai Jiacheng also believes vertical division system is a final goal of division system for China's travel agencies. At this stage, different travel agencies are positioned clearly in the market. Respective division in different business market and different links of travel operations has been formed and will not be changed easily [8].

Segmented division system in China is involved in a wide range with mutually overlapped businesses and mutually covered markets. In reference with American division system, travel agencies of different sizes shall be positioned as wholesalers, retailers and agents to construct a vertical division system where each performs its duties in close cooperation.

\section{Main Reasons for Construction of Vertical Division System in China's Travel Agency Industry Market}

\subsection{Vertical Division of Labor System Has Advantages}

\subsubsection{Advantages of Vertical Division System}

Wholesale operator and retail agents are subject to definite work division and perform their respective duties. Wholesalers focus on production, organization and promotion of travel products, and reception, of which price is much lower than sum of price of single item. As a result, travelers save their money and market demand is stimulated. Retail agents are specialized in agency and sale of products, expand everywhere as sale antenna of wholesale operators, provide wholesale operators with source of customers, and gain considerable commission. The relation between them is cooperation and interdependence, which prevents meaningless competition and forms a virtuous circle.

\subsubsection{Lower Market Risk}

Market trade costs are saved and market risks are lower. Retail agents save market trade costs for upstream suppliers and travelers. For travel wholesale operators, not only market trade costs are reduced, but also market risks are lower and growth of travel market is stimulated. Growth of group package tour boosts 
standardized production of travel product and marketing of a large scale, makes service operations of employees proficient and enhances operation efficiency of enterprises and the whole industry.

\subsubsection{Scale Operation}

Specialized operation and scale operation benefit from vertical division system. Operation of a large scale helps to improve market competitiveness of travel agencies, obtain benefits from scale operation and lower or transfer common operation risks. As a result, a competence to exclude competitors is obtained, competition expense saved and competitive strength improved. Pattern of travel agency market, formed in vertical division system and through market competition, is beneficial to orderly and healthy development of travel market.

\subsection{Disadvantage in Horizontal Division System}

\subsubsection{Constraint Market Mechanism Function}

Too many regulations of government to travel agency industry will easily cause negative effect for market inequality and hindering market development, and cause generating of contracting and subordinating of "agency in agency" and "department in department" etc. [9]. Market economy system, market plays a foundation role in optimizing allocation of production element and resource. At the time of market failure, governments need to exert influence through regulation and guidance in macro level. However, in terms of current system, administrative power interferes too much on micro lever that should have been opened. Enterprises that specially engage in product design, development and production or specially engage in production wholesale and agent retail can not be formed, which seriously constraint advantage exertion and dynamic display of enterprises and market mechanism function.

\subsubsection{Constraint Innovation Ability of Travel Agency}

Many travel agencies with relatively small scale and strength do not pay attention to product and service innovation, and blindly stimulate large-scale travel agency with strength. Once products of large-scale travel agency are developed, they will be stimulated in extreme short time [10]. which directly damage motivation of product and service innovation. It easily causes product stimulation and similarity in the whole industry and low-level repetitive construction of travel agency, intensifies vicious competition in the industry, and makes the whole industry stay in vicious circle with low-efficiency operation.

\subsubsection{Cause Low-Level Price Competition}

Small and medium travel agencies have limited capital and talent, but its business activity involves the whole links for product design and sales service etc.. Lack of innovation input for product and service end causes it to compete with large-scale travel agency in the same product with relatively low cost [11]. Developing vicious price competition by taking advantage of using product with poor quality and service will cause market disorder. 


\subsubsection{Difficult to Realize Scale Economy}

Under horizontal division system, asset stock can not be transferred to largescale travel agency, and resource optimization allocation in the whole industry can not be realized to form healthy competition situation of scale economy and effective competition. Under horizontal division system, there is no obvious specialty division between travel agencies with different scales, and travel agencies with different scales and resources participate in market competition in the similar mode. Its target clients are repetitive and products are similar. During the process of competing with small and medium travel agencies, large-scale travel agency can not exert advantages of capital, talent and scale, and it is difficult to realize scale economy. It causes the overall strength of Chinese travel agency weak, and a majority of travel agencies lacks strategic planning and market positioning busy with price competition and product stimulation. They have no time to attend to training of brand establishing and human resource, and the overall lacking of international competitiveness for travel agency industry is finally caused.

\section{The Main Obstacle for Vertical Division System Construction in Travel Agency Industry in China}

\subsection{Industry Market Concentration Is Low, and Scale Economy Has Not Been Formed}

Market concentration refers to the percentage for the several largest enterprise production and sales occupying the total industry production and sales in all industries, and is one concept for characterizing structural characteristic of industry market and market control of big enterprise. In general, the lower the industry market concentration is, the weaker the market monopoly degree is, and the smaller the market power is; the higher the industry market concentration is, the larger the enterprise scale is, and the greater the enterprise market power and obtained expected benefit are. Scales for travel agency enterprises in China are small, and industry market concentrations are low. Relatively large travel agencies in industry have not taken root in product chain to form scale increasing of collectivization and industrialization, and there is no big enterprise with international competitiveness that can really control market. Market structure with many enterprises and low concentration is not beneficial to operation and competitiveness of market.

\subsection{Market Environment Has Not Been Mature}

On one hand, one important condition for vertical division system is that operators for travel whole sales and retail agency can realize win-win under the condition of vertical division, and this kind of win-win is superior to independent operation under the condition of horizontal division. Li Tianyuan discussed the diseconomy and irrationality of travel agencies in China subject to indirect sales channel that is absence for large-scale travel agency group that can provide 
market support of agency system, and he thought that there had been not survival conditions for travel agent [12]. On the other hand, a majority of business volume for travel agency in European and American countries comes from agency for single travel product of company and travel hotel etc., and not just come from sales agent for package travel products. For part of industries for railway and civil aviation etc. related to travel industry has monopoly property, it hinders realization of agency system for travel agency in China. Xia Zancai discussed unequal trading status of weak travel agency and civil aviation and railway departments with strong monopoly under this kind of condition for non-marketization of key supply department, which became the important obstacle to realize agent system of travel agency in China [13].

\subsection{Industry System Constrains Exertion of Market Mechanism Function}

According to modern market economy theory [14], function of government in market economy is to provide "system environment" for economic operation, and it is mainly to "provide rule of law, property right protection, market order and infrastructure". At present, over interference of government is the main problem to constraint market mechanism. Affected by old system, it is not beneficial to training competitive capacity and anti-risk capacity of domestic travel agencies. Under horizontal division system, too many micro regulations of governments at all levels on travel agency industry easily cause market inequality, and it mainly presented as repressing positivity and creativity of enterprise production and operation, seriously weakening market competitiveness of enterprise and prevailing of local protectionism etc., which hinders collectivization and network development of travel agency. Related laws and regulations are not sound, and industry management system is not reasonable, which makes development for travel agency enterprise lack some environment guarantee [15].

Formation for vertical division system in travel agency industry is determined by factors in two aspects internally and externally. Seen externally, relatively sound system environment for market competitiveness and competition and motivation from foreign travel agency shall be established [16]; seen internally, travel agent shall have strong travel product research, development, production capacity and obvious comparison advantage, and can bring some profit to travel agent [17]. Reasonable division system of travel industry can be established on a new development platform only like this.

\section{Research Conclusion}

\subsection{Positive Guidance of Government Is the Key to Construct Vertical Division System}

Government can play guidance function, train healthy external market environment, quicken travel legislation and confirm legitimacy for natural division system in travel agency industry through law from. Through quickening con- 
struction for related travel laws and regulations, division between industries and departments shall be broken. Travel legislation is the law guarantee to normalize enterprise subject qualification and its operation behaviors of travel agency, and improving management system for travel agency is the system guarantee to implement effective management and supervision for it. Sound laws and regulations and management system are equal to providing one just, fair, open, standardized and orderly market environment. Through formulating reasonable economic policy, it can more effectively guide development for travel agency enterprise, break industrial monopoly, eliminate local protection and realize reasonable allocation of travel sales resource, which is the important factor to promote implementing for travel agency system.

\subsection{Reasonable Market Pattern Is the Foundation to Construct Vertical Division System}

Constructing large-scale travel agency group is beneficial to realizing scale operation of enterprise, quickening integrated operation of travel agency enterprise, promoting collectivization development based on market mechanism, constructing industrial leaders, and strengthening market influence and industrial status of large-scale travel agency. Through forward integration, backward integration and international integration, large-scale travel agency integrates upstream and downstream resources of travel value chain to construct one value chain with relatively strong competitiveness. With the increasing deepening for reform of property right system and continuous increasing for market openness in China, reasonable market pattern will slowly form to provide a foundation for market operation to construct vertical division system.

\subsection{Innovation and Promotion of Technology Is the Guarantee to Construct Vertical Division System}

Agency approaches in a variety of ways and travel agency enterprises with various types based on travel business difference shall be explored with efforts. They can be research enterprise, production enterprise or marketing enterprise for products of travel agency, and they can be also two or all of the latter three kinds of types. In case natural division system is in harmony with the market mechanism, enterprises can automatically confirm business scope, and better exert advantage to be with more energy and form a powerful pattern for specialized division and cooperation of enterprises with various forms. With the help of information technology, core competitiveness for travel agency shall be improved. Improving technology innovation capacity for travel agency enterprise and quickening popularizing and spreading for information technology construction of travel agency are important guarantees to improve core competitiveness of travel agency. Travel agency can obtain greater development opportunity through setting E-commerce website and integrating its own resource. Information construction of travel agency shall be strengthened. Through application of information technology, optimizing operation procedure and resource alloca- 
tion, lowering internal trading cost, realizing effective client relation management and reducing unusual business loss shall be conducted to realize network operation to improve operation benefit for travel agency enterprise.

\section{Research Limit and Outlook}

Monopoly and protection in different areas and industries in China make closely related sales business not related, which wastes sales resources, and also causes sales cost for per single product to stay at a high level. Only breaking industry monopoly and eliminating local protection may realize reasonable allocation of travel sales resource. The research in the Thesis was one simple discussion based on practical condition. With the technology development and system reform, construction environment of division system will be gradually improved, and research in the future can start from China's actual situations to discuss further in many perspectives and aspects to promote division system construction for travel agency industry in China.

\section{References}

[1] Yu, X.T. and Liu, J. (2016) The Problem and Countermeasure Analysis of Price Competition in Travel Agency from the Perspective of Division of Labor. Chinese Market, 51, 207-209.

[2] Zeng, L. and Chen, G.H. (2013) Categorizing Travel Agencies in China Using Retail Sales as the Analysis Unit. Tourism Tribune, 28, 9-13.

[3] Yuan, H.Y. (2014) A Comparative Analysis of the Division System of Chinese and Foreign Travel Agencies. Art Technology, 27, 353-353.

[4] Chen, X.H. (2004) Research on the Optimization of Division System of Travel Agencies in China. Shandong Normal University, Jinan.

[5] Wu, J.H. (2010) A Comparative Study of the Division System of Chinese and Foreign Travel Service Industry. Chinese Business Theory, 8, 155-156.

[6] Wang, L. and Liu, L.L. (2008) Strategic Choice of Large Scale Travel Agencies under Vertical Division of Labor System in China. Industry and Technology Forum, 7, 48-50.

[7] Huang, L. (2007) Study on the Future Division of Labor System of Travel Agency. Entrepreneur World Monthly, 4, 152-153.

[8] Cai, J.C. (1999) The State of the Art and Trend of Travel Agency System in China. Tourism Tribune, 6, 9-13.

[9] Meng, F.Z. (2010) Incentive Analysis and Legal Regulation of the Affiliated Contract of Travel Agency. Tourism Tribune, 27, 106-112.

[10] Li, G. (2012) Research on Product Design of Travel Agency Based on Conjoint Analysis. Hainan University, Haikou.

[11] Zhao, Y. and Suo, Z.L. (2010) Research on Product Innovation Strategy of Travel Agency Based on Price Competition Theory. Business Studies, 12, 92-96.

[12] Li, T.Y. and Wang, J. (2001) Why the Vertical Division of Labor in China's Travel Agency Industry Is Difficult to Achieve?-A Reflection on the Vertical Division of Labor in China's Travel Agency Industry. Tourism Tribune, 16, 23-26.

[13] Xia, Z.C. (2002) Analysis on the Deep Obstacles and Countermeasures of Travel Agency System in China. Journal of Social Science of Hunan Normal University, 31, 
71-77.

[14] Guo, Z.Q. and Shen, M.L. (2013) Keynes's Great Contribution to the Theory of Modern Market Economy. Foreign Economic Theory and Chinese Research Reports.

[15] Jiang, Y. (2013) Legal Regulation of Unfair Competition in Travel Agencies. Southwestern University of Finance and Economics, Chengdu.

[16] Zhong, L.P. (2015) Research on Marketing Strategy of Xintiandi Travel Agency. Hunan University, Changsha.

[17] Wu, D. (2010) Probe into the Supply Chain Management of Travel Agency. Journal of Hunan College of Finance and Economics, 26, 43-45. 